\title{
How to Increase Customer Retention on Central Java MSMEs?
}

\author{
Rifda Nabila ${ }^{1}$, Arna Asna Annisa ${ }^{2}$, Fathan Budiman ${ }^{3}$, Endah Nur Fitriyani ${ }^{4}$, Yuda \\ Trishananto $^{5}$ \\ \{rifdanabila@iainsalatiga.ac.id ${ }^{1}$, arnaannisa@iainsalatiga.ac.id², fathan@iainsalatiga.ac.id ${ }^{3}$, \\ endahfitriyani@iainsalatiga.ac.id ${ }^{4}$, yudhatrishananto@iainsalatiga.ac.id ${ }^{5}$ \}
}

Faculty of Islamic Economics and Business, IAIN Salatiga - Indonesia ${ }^{1,2,3}$

\begin{abstract}
The halal industry shows very rapid development throughout the world, including in Indonesia. The biggest contributor to the halal industry is micro, small and medium enterprises (MSMEs). MSMEs are faced with complex conditions and are required to be able to determine strategies to overcome existing conditions. One of them is by running an effective and efficient marketing concept.This research conducted to test and analyze the effect of product innovation, Price Level s and halal labels on Customer Satisfaction and their impact on Customer Retention of halal-labeled MSMEs products in Central Java. This type of research is quantitative research. The sample of this study was 200 respondents with the criteria of ever buying MSMEs products that were labeled halal. The data analysis technique used is Structural Equation Modeling-Partial Least Square (SEM-PLS).The results showed that the Price Level and halal label affect Customer Satisfaction and Customer Satisfaction also influence Customer Retention, while product innovation does not affect Customer Satisfaction
\end{abstract}

Keywords: Product Innovation; Price; Halal Label; Customer Retention; MSMEs

\section{Introduction}

The challenge that is never obsolete for MSMEs is their ability to be able to survive in the market and become major. On the other hand, MSMEs have a significant contribution to economic growth, so an evaluation of MSME business development strategies is needed. Their potential is evidenced by their ability to withstand the financial crisis in 1997 to 1998 , even being able to absorb 85 million - 107 million workers until 2012 [1]. This showed how MSMEs can be managed to be independent and survive the national economic instability.

The changes of socio-economic that take place quickly, making marketing of MSME products must be accompanied by product innovation so that it can meet changing needs and will bring satisfaction to customers. Satisfaction that arises from the consumption of MSME products will make consumers repurchase therefore it can be used as a measurement tool to demonstrate the potential growth of MSMEs.

Competition in similar products is often associated with price levels in the market. This is a measure of the ability of consumers to be able to reach MSME products. At the appropriate price level, customer retention can be created as part of a marketing strategy. In fact, market expansion can be carried out by adjusting the price level of MSME products in the market.

The aspect of halal is a basic requirement of Muslims. However, this has become a universal indicator of the health and good parameters of a product. Consumer convenience for products labeled as halal becomes important for purchasing decisions therefore that satisfaction will be more easily obtained by consumers [2]. 


\section{Literature Review}

\subsection{Product Innovation}

Product Innovation is defined as the process of introducing new products that bring economic success to the company and social success for consumers and the wider community/environment [3]. Product Innovation is also defined as an innovation that is used throughout the company's operations where a new product is created and marketed, including innovation in all functional processes/uses.

Product innovation needs to get the main attention of the company, considering that this strategy is closely related to marketing activities carried out by the company. Empirical results showed that when a combination of intellectual resources and product innovation capabilities in addition to a combination of reputation resources and high marketing capabilities, SME growth can be increased.

According to Tjiang and Harjanti [4] there are three dimensions of product innovation namely: (1) Product Quality: The ability of a product to perform its functions, which includes durability, reliability, accuracy generated and fuel savings, (2) Product Features: Competitive means to differentiate products from one another, or between products owned by competing products, that is, product features and product features added, and (3) Product Style and Design: Different way to add value to customers. Style only explains the appearance of a particular product, whereas design has a concept more than style. Like the color combination of the product, the development of models and shapes.

\section{a. Price Level}

In general, price is the amount of money that must be sacrificed by consumers to get a product or service. Prices is an element of the marketing mix generates income while others produce costs. Prices can be an attraction or determinant in making purchasing decisions. However, prices can also be a barrier or obstacle in purchasing decisions[4].

Inappropriate decision making in pricing will cause a decrease in consumer buying interest in these products. At certain times, consumers will judge the quality of the product based on the price level if they only have limited information about the product. The higher the price of a product, the higher the quality of the product. However, if consumers value a product not too high, then they are reluctant to buy the product if the price is high specified.

\section{b. Halal Label}

Halal has become part of the lifestyle of the global community, which means that halal guarantees have been recognized by the WTO (World Trade Organization) where international trade organizations are very concerned about halal certification or halal labeling to ensure the protection of Muslim consumers around the world [5]. In Indonesia there is a special institution has the authority to choose and audit products consumed by Muslims to ensure halal aspects, namely the Institute for Drug and Food Control and Circulation Indonesian Ulema Council (LPPOM-MUI), subsequently the government issued Law number 33 of 2014 concerning halal product guarantees hereinafter referred to as JPH. To implement the Act the government established the Halal Product Guarantee Agency (BPJPH). In carrying out its duties BPJPH cooperates with relevant ministries and /or institutions such as the Halal Examination Institute and the Indonesian Ulema Council. Cooperation between BPJPH and MUI is carried out in the form of Halal Auditor certification, determination of Product 
Halaliness, and accreditation of the Halal Auditing Agency. Determination of Product Halaliness issued by MUI in the form of Decision on Halal Product Determination [6][7].

Halal label is the granting of halal marks or written evidence as a guarantee of halal products with Halal writing in Arabic letters, other letters and motor codes from the Minister issued on the basis of halal inspection from halal inspection institutions established by MUI, halal fatwas from MUI, halal certificates from MUI as a valid guarantee that the product referred to is halal is consumed and used by the community in accordance with Islamic regulations [2].

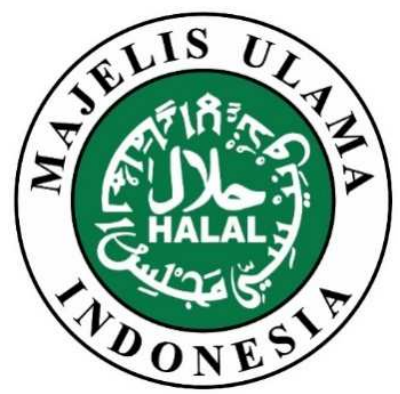

Fig.1. Logo of Label Halal MUI

Muslims have the right to receive legal protection and guarantee for the halal goods consumed and used [7]. With the halal label listed on the product packaging, it will directly influence consumers to use the product. The emergence of a sense of security and comfort in consuming products will make someone make a purchasing decision [2].

\section{c. Customer Satisfaction}

The concept of marketing emphasizes the importance of customer satisfaction in supporting a company's success in realizing the expected goals [8]. Consumer satisfaction is the level of consumer feelings after comparing between what is received and expectations [9]. Consumer satisfaction is someone's happy or disappointed feelings that emerges after comparing the expected performance (results) of services to the expected performance [4].

Sumarwan [10], satisfaction is the level of feeling after comparing the performance or perceived results with expectations. So the level of satisfaction is a function of the difference between perceived performance and expectations. If the performance is below expectations, then the customer will be disappointed, if the performance is in line with expectations, then the customer will be very satisfied. So the customer will evaluate the product or service in terms of whether the product or service meets the needs and meets expectations [11].

The five dimensions shape customer satisfaction are: Price, Service Quality, Product Quality, Emotional Factor, and Efficiency (Easeness) .

\section{d. Customer Retention}

The definition of customer retention is all forms of activities and activities directed by producers or companies to maintain good and sustainable interactions with customers. Customer retention refers to the ability of a business or product to retain its customers for a certain number of periods. High customer retention means customers of a product or business tend to return or make repeat purchases, continue to buy or not turn to other 
products/businesses, or for non-use entirely. In general, the definition of customer retention is any activity or effort to reduce customer turnover.

Customer retention starts with the first business contact with the customer and continues throughout life or as long as the customer is active. The ability of a business to attract and retain new and old customers, not only with products or services. The retention process also includes how to provide services for customers, because customers are assets for business people therefore it is only natural to provide the best service.

Customer retention on the other hand is determined by different studies in different ways. This studies stated that customer retention is the continuity of business relationships between customers and companies [12]. Customer retention is more than giving customers what they expect. Customer retention is a customer expectation so that it becomes a loyal customer for the company. The retention and attractiveness of new customers is used as a driver to increase market share and revenue. In customer retention, it's important for companies to know how to serve their customers because after-sales service is an important driver for customer retention [13].

\subsection{Framework of the Research}

This study identifies how Product Innovation, Price Level and Halal Label variables will affect Customer Satisfaction prior to the stage of Customer Retention.

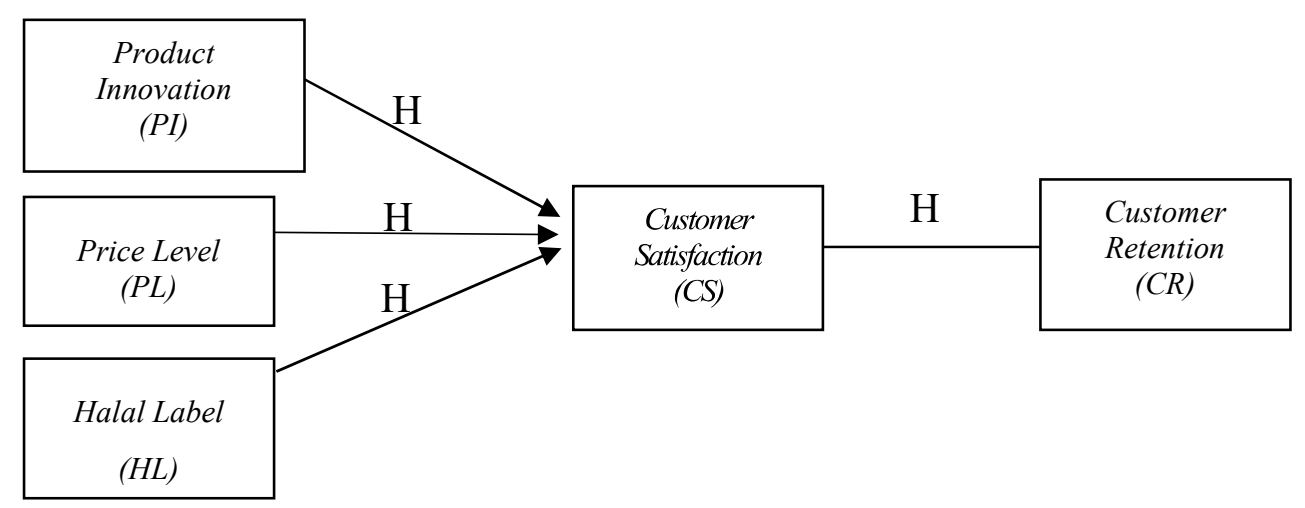

Fig.2. Framework of the Research

\subsection{Hypothesis of the Research}

Hypothesis of this study is as follows:

$\mathrm{H}_{1}: P I$ has an effect on $C S$

$\mathrm{H}_{2}: P L$ has an effect on $C S$

$\mathrm{H}_{3}: H L$ has an effect on $C S$

$\mathrm{H}_{4}:$ CS has an effect on Customer Retention

$\mathrm{H}_{5}: C S$ mediates an effect of $P I$ on $C R$

$\mathrm{H}_{6}: C S$ mediates an effect of $P L$ on $C R$

$\mathrm{H}_{7}: C S$ mediates an effect of $H L$ on $C R$ 


\section{Method}

This type of research used in this research is explanatory research. This explanatory research is a type of research used to determine the size of the influence between endogenous variables and exogenous variables.

This study uses primary data obtained directly from MSMEs that already have MUI halal certificates. The population in this study were all MSMEs in Central Java which received halal certificates from MUI from 2012-2018, totaling 500 MSME units. The analysis technique used is to use Structural Equation Modeling (SEM). The analytical tool used in this study is Partial Least Square (PLS).

The technique of sampling in this study was conducted by purposive sampling. While the number of samples used is in accordance with the maximum likelihood estimation technique, which requires a sample between 100-200 [14]. The sample size in a study must have a minimum sample size of five times the number of questions analyzed [15] and the number of questions in the research questionnaire consists of 26 questions. In this study the number of respondents taken was 200 respondents therefore in this study it was considered sufficient.

\section{Result And Discussion}

\subsection{Result}

This study uses structural equation models that are analyzed using the SmartPLS 3.3.0 program.

\section{a. Evaluation of Outer Model}

Outer model is used to determine the validity and reliability of the data that connects the indicator with its latent variable.

\section{b. Validity of Convergent}

An indicator is declared valid if it has a loading factor above 0.7 against the intended construct. The SmartPLS output for loading factor can be seen in the Figure below:

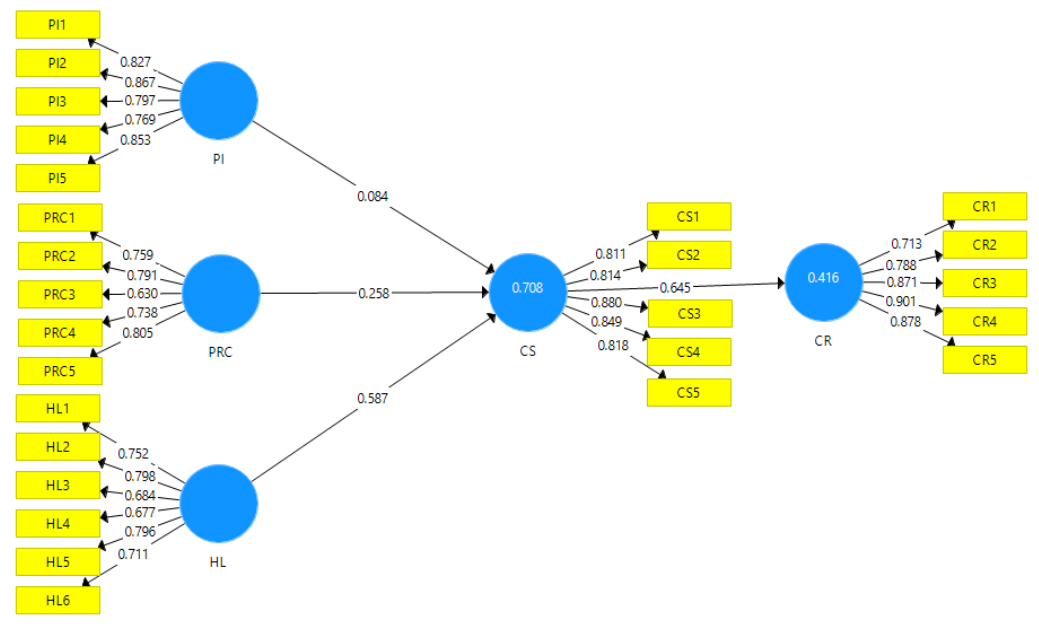

Fig.3. Results of Algorithm Analysis 
Based on the results of the PLS Algorithm it can be seen that the loading factor of each indicator is above 0,7 against the intended construct, which means that all indicators are valid.

\section{c. Validity of Discriminant}

Discriminant validity is related to the principle that measurement of different constructs should not be highly correlated.

Table 1. Latent Variabel Correlations

\begin{tabular}{cccccc}
\hline & $\begin{array}{c}\text { Product } \\
\text { Innovation }\end{array}$ & $\begin{array}{c}\text { Price } \\
\text { Level }\end{array}$ & $\begin{array}{c}\text { Halal } \\
\text { Label }\end{array}$ & $\begin{array}{c}\text { Customer } \\
\text { Satisfaction }\end{array}$ & $\begin{array}{c}\text { Customer } \\
\text { Retention }\end{array}$ \\
\hline Product Innovation & 1.000 & & & & \\
Price Level & 0.767 & 1.000 & & & \\
Halal Label & 0.561 & 0.667 & 1.000 & & \\
Customer Satisfaction & 0.611 & 0.713 & 0.806 & 1.000 & \\
Customer Retention & 0.520 & 0.534 & 0.669 & 0.645 & 1.000 \\
\hline & (Source: Primary data processed, 2020) &
\end{tabular}

From the comparison of the correlation coefficient of latent variables in table 1 above, it can be seen that

1. Product Innovation has a relationship of 0,767 with Price Level

2. Product Innovation has a relationship of 0,561 with Halal Label

3. Product Innovation has a relationship of 0,611 with Customer Satisfaction

4. Product Innovation has a relationship of 0,520 with Customer Retention

5. Price Level has a relationship of 0,667 with Halal Label

6. Price Level has a relationship of 0,713 with Customer Satisfaction

7. Price Level has a relationship of 0,534 with Customer Retention

8. Halal Label has a relationship of 0,806 with Customer Satisfaction

9. Halal Label has a relationship of 0,669 with Customer Retention

10. Customer Satisfaction has a relationship of 0,645 with Customer Retention

Based on these interpretations, it can be analyzed that: All latent variables in this study have a relationship of more than $50 \%$, it can be concluded that all latent variables in this study have a large enough relationship. And the relationship is in accordance with the analysis model in the research has been described in this study.

\section{d. Reliability Test}

In addition to using the validity test for constructs, it is also necessary to test reliability which is measured by using Composite Reliability and reinforced by the Cronbach's Alpha value of the indicator block that measures the construct. Composite Reliability results will show a satisfactory value if it is above 0,7 and Cronbach's Alpha above 0,60. The Composite Reliability and Cronbach's Alpha values are shown in the table below:

Table 2. Value of Composite Reliability and Cronbach's Alpha

\begin{tabular}{|c|c|c|}
\hline & Composite Reliability & Cronbachs Alpha \\
\hline Product Innovation & 0.913 & 0.881 \\
\hline Price Level & 0.862 & 0.803 \\
\hline Halal Label & 0.887 & 0.833 \\
\hline Customer Satisfaction & 0.920 & 0.891 \\
\hline Consumer Retention & 0.919 & 0.895 \\
\hline
\end{tabular}

(Source: Primary data processed, 2020) 


\section{e. Evaluation of Inner Model}

After using the estimated model that meets the Outer Model criteria, the next is to test the structural model (inner model) using the R-Square model for endogenous constructs and ttests as well as the significance of the structural parameter coefficients.

Table 3. Value of R-Square

\begin{tabular}{cc}
\hline & R Square \\
\hline Customer Satisfaction & 0.416 \\
Customer Retention & 0.708 \\
\hline (Source: Primary data processed, 2019)
\end{tabular}

The R-Square value for the Customer Satisfaction variable is 0.416 , which means the Customer Satisfaction variable can be explained by the Product Innovation, Price Level and Halal Label variables by $41,6 \%$, and the remain is influenced by other variables.

For Customer Retention variability can be explained by the Customer Satisfaction variable of $70,8 \%$ and the remain is influenced by other variables not examined in this study.

\section{f. Testing of Hypothesis}

The research hypothesis can be tested using the bootstrapping method by looking at significant models in testing structural models.

Table 4. Hypothesis Testing

\begin{tabular}{|c|c|c|c|c|}
\hline Hypothesis & $\begin{array}{l}\text { Original } \\
\text { Sample } \\
\text { (O) }\end{array}$ & $\begin{array}{c}T \\
\text { Statistic }\end{array}$ & $\begin{array}{c}P \\
\text { Values }\end{array}$ & Result \\
\hline $\begin{array}{c}\mathrm{H}_{1}: \text { Product Innovation has an effect on } \\
\text { Customer Satisfaction }\end{array}$ & 0,084 & 1,073 & 0,238 & $\begin{array}{l}\text { Cannot be } \\
\text { proven }\end{array}$ \\
\hline $\begin{array}{c}\mathrm{H}_{2} \text { : Price Level has an effect on Customer } \\
\text { Satisfaction }\end{array}$ & 0,258 & 3,559 & 0,000 & Proven \\
\hline $\begin{array}{c}\mathrm{H}_{3}: \text { Halal Label has an effect on Customer } \\
\text { Satisfaction }\end{array}$ & 0,587 & 11,068 & 0,000 & Proven \\
\hline $\begin{array}{c}\mathrm{H}_{4}: \text { Customer Satisfaction has an effect on } \\
\text { Customer Retention }\end{array}$ & 0,645 & 19,315 & 0,000 & Proven \\
\hline $\begin{array}{c}\mathrm{H}_{5}: \text { Customer Satisfaction mediates effect } \\
\text { of Product Innovation on Customer } \\
\text { Retention }\end{array}$ & 0,054 & 1,053 & 0,293 & $\begin{array}{l}\text { Cannot be } \\
\text { proven }\end{array}$ \\
\hline $\begin{array}{c}\mathrm{H}_{6}: \text { Customer Satisfaction mediates effect } \\
\text { of Price Level on Customer } \\
\text { Retention }\end{array}$ & 0,166 & 3,495 & 0,001 & Proven \\
\hline $\begin{array}{c}\mathrm{H}_{7}: \text { Customer Satisfaction mediates effect } \\
\text { of Halal Label on Customer } \\
\text { Retention }\end{array}$ & 0,379 & 9,083 & 0,000 & Proven \\
\hline
\end{tabular}

Based on Table 4 it can be seen that Product Innovation has no effect on Customer Satisfaction, namely with P-Values of $0,238(>0,05)$. Thus the H1 hypothesis in this study was rejected.

Price Level and Halal Label variables have a significant influence on Customer Satisfaction with P-Values Price Level 0,000 $(<0,05)$ and P-Values Halal Label 0,000 $(<0,05)$. Thus the hypotheses $\mathrm{H} 2$ and $\mathrm{H} 3$ are accepted. And for Customer Satisfaction variable has a significant effect on Customer Retention with P-Values $0,000(<0.05)$. Thus the H4 hypothesis is accepted. 
The value of Original Sample estimate is positive, that is 0,258 for the Price Level of Customer Satisfaction; 0,587 for Halal Label for Customer Satisfaction and 0,645 for Customer Satisfaction for Customer Retention, which shows the direction of influence between Price Level on Customer Satisfaction, Halal Label on Customer Satisfaction, Customer Satisfaction on Customer Retention is positive.

The indirect results of effect estimation show that the relationship between Product Innovation and Customer Retention mediated by Customer Satisfaction has a value of 0,293. This means that Customer Satisfaction is not able to mediate the relationship between Product Innovation and Customer Retention. While the relationship between Price Level and Customer Retention mediated by Customer Satisfaction has a value of 0,001 and the relationship between Halal Label and Customer Retention mediated by Customer Satisfaction has a value of 0,000, which means that Customer Satisfaction is able to mediate the relationship between Price Level and Halal Label with Customer Retention.

\subsection{Discussion}

The results of this study, obtained findings that are different from the findings of previous researchers [16], [17], [18], [19], which showed that the Product Innovation variable had a significant effect on Customer Satisfaction. In contrast, the results of this study provide findings that Product Innovation has no effect on Customer Satisfaction. This indicates that Product Innovation does not affect the level of consumer satisfaction in consuming MSME products.

Kotler indicates the importance of the price element in consumer decision making. Price is often associated with the quality of a product. Consumers tend to use price as an indicator of quality and satisfaction obtained from a product. Determination of Price Level The price of a product must pay attention to the amount of profit desired by the company and the intended consumer purchasing power.

Product attributes such as Halal Label affect Customer Satisfaction, indicating that consumers who are satisfied with the value provided by a product are very likely to be consumers for a long time. The better the consumer's assessment of the product, the higher customer satisfaction will be [20]. This is in line with previous research, which states that products that already have a halal label will increase customer confidence to consume these products because they are sure of their ingredients [21]. This can encourage consumers to buy back the product. If consumers make purchases continuously, it means they are satisfied with Halal products.

The purchase of halal products has also been explained in the Al-Quran about the recommendation to consume halal food, as explained in Al-Quran Surah An-Nahl verse 114:

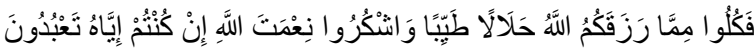

Meaning: Then eat the lawful again from the fortune that God has given you; and be grateful to Allah, if you only worship Him. (Q.S An-Nahl: 114)

Based on the above verse, it has been explained that Muslims are ordered to eat halal (permissible) and give thanks for the blessings given by Allah SWT. Thus the halal label becomes important because it is a suggestion of Islamic law.

Customer Satisfaction influences Customer Retention, so businesses are expected to be able to form a stimulus that can strengthen customer satisfaction. The stimulus given is related to the ability of MSME products in providing good quality. With this stimulus, it is expected 
to increase the level of customer satisfaction felt by consumers. The determination of postpurchase behavior of a product is based on customer satisfaction or dissatisfaction [22]. The results of this study are supported by the theory of Aaker [23], which states that consumers will be loyal to a product if he gets satisfaction from the product. Satisfaction will make the sense of pleasure in the minds of consumers and consumers will be very possible to make a repeat purchase. In addition, the results of this study are also in accordance with previous studies which explain that the Customer Satisfaction affects Customer Retention [24], [25], [26], [27].

\section{Conclusion}

The findings of this study indicate that the determination of the Price Level of MSME products as well as the provision of Halal Labels has an influence on customer satisfaction, which in turn affects the level of consumer retention. Whereas Product Innovation has no influence on customer satisfaction. Based on these findings, it is expected that MSMEs will always provide prices in accordance with the quality of the products offered and also maintain the halal nature of the products sold.

\section{Acknowledgment}

The author would like to thank profusely to all those who have supported this research, especially to the owners of MSMEs who have agreed to be respondents in this study and also to academics at IAIN Salatiga.

\section{Reference}

[1] Y. R. Suci, "Perkembangan UMKM (Usaha Mikro Kecil dan Menengah) di Indonesia," J. Cano Ekon., vol. 6, no. 1, pp. 51-58, Mar. 2017, doi: 10.30606/CE.V6I1.1239.

[2] I. Alfian, "Analisis Pengaruh Label Halal, Brand dan Harga Terhadap Keputusan Pembelian di Kota Medan," At-Tawassuth, vol. Vol.2, No., p. 127, 2017.

[3] A. Fontana, Innovate We Can! Bekasi: Cipta Inovasi Sejahtera, 2011.

[4] and K. L. K. Kotler, Philip, Marketing management. Upper Saddle River, N.J: Pearson Prentice Hall, 2009.

[5] M. T. Yani et al., "MUSLIM CONSUMER BEHAVIOR IN CONSUMING HALAL," vol. 3, no. 2, pp. 161-173, 2019, doi: 10.26740/al-uqud.v3n2.p161-173.

[6] M. R. Siregar, A. Alam, U. Muhammadiyah, and U. Muhammadiyah, "HAL ā L LABEL ON FOOD PRODUCTS BY MUI ( INDONESIAN ULAMA COUNCIL ) AND STUDENTS PURCHASING DECISION OF FACULTY OF BUSINESS AND ECONOMIC," vol. 1, no. 1, pp. 1-30, 2018.

[7] M. Ilyas, "Sertifikasi dan Labelisasi Produk Halal Perspektif Maslahat," pp. 357-376, 2017.

[8] D. Anggraeni, S. Kumadji, and S. Sunarti, "PENGARUH KUALITAS PRODUK TERHADAP KEPUASAN DAN LOYALITAS PELANGGAN ( Survei pada Pelanggan Nasi Rawon di Rumah Makan Sakinah Kota Pasuruan)," J. Adm. Bisnis S1 Univ. Brawijaya, vol. 37, no. 1, pp. 171-177, 2016.

[9] H. Umar, Study Kelayakan Bisnis. Jakarta: Gramedia Pustaka Utama, 2005. 
[10] I. Panjaitan, "PENGARUH PELAYANAN DAN HARGA PADA GO-JEK TERHADAP KEPUASAN KONSUMEN DENGAN MINAT SEBAGAI VARIABEL MODERATING (Study Kasus Pada Mahasiswa Universitas 17 Agustus 1945 Jakarta)," Media Stud. Ekon., vol. 19, no. 2, pp. 43-55, 2016.

[11] V. A. Bitner, M.J. and Zeithaml, Service Marketing (3rd ed). New Dehli: Tata McGrew Hill, 2003.

[12] T. Gerpott, W. Rams, and A. Schindler, "Customer retention, loyalty, and satisfaction in the German mobile cellular telecommunications market," Telecomm. Policy, vol. 25, pp. 249-269, May 2001, doi: 10.1016/S0308-5961(00)00097-5.

[13] et al Saeed, Rashid, "Impact of Customer Relationship Management on Customer Satisfaction," World Appl. Sci. J., vol. 26 (12):, pp. 1653-1656, 2013.

[14] W. T, Analisis Structural Model Menggunakan AMOS. Yogyakarta: Universitas Atmajaya Yogyakarta, 2009

[15] et al Hair, Multivariate Data Analysis Pearson International Edition Edition 6. New Jersey, 2006.

[16] A. R. Nemati, K. Khan, and M. Iftikhar, "Impact of innovation on customer satisfaction and brand loyalty, a study of mobile phones users in Pakistan,” Eur. J. Soc. Sci., vol. 16, no. 2, pp. 307-314, 2010.

[17] B. Diaw and G. Asare, "Effect Of Innovation On Customer Satisfaction And Customer Retention In The Telecommunication Industry In Ghana: Customers ' Perspectives," Eur. J. Res. Reflect. Manag. Sci., vol. 6, no. 4, pp. 15-26, 2018.

[18] B. Aditi and H. . Hermansyur, "Pengaruh Inovasi Dan Kreativitas Terhadap Kepuasan Konsumen Pada Umkm Di Kota Medan,” Manaj. Tools, vol. 7, no. 1, pp. 1-9, 2017.

[19] P. Sukarmen, A. Sularso, and D. Wulandari, "Analisis Pengaruh Inovasi Produk Terhadap Kepuasan Konsumen Dengan Keunggulan Bersaing Sebagai Variabel Intervening Pada Produk Gula Pasir Sebelas (Gupalas) Pabrik Gula Semboro Ptp Nusantara XI (Persero),” J. Ekon. Akunt. dan Manaj., vol. 12, no. 2, pp. 64-79, 2015.

[20] J. E. Panjaitan and A. L. Yuliati, "Pengaruh Kualitas Pelayanan Terhadap Kepuasan Pelanggan Pada JNE Cabang Bandung [The Influence of Service Quality on Customer Satisfaction at JNE Branch in Bandung]," DeReMa (Development Res. Manag. J. Manaj., vol. 11, no. 2, p. 265, 2016, doi: 10.19166/derema.v11i2.197.

[21] Kusnandar, "Pengaruh Citra Merek dan Kesadran Label Halal Produk Kosmetik La Tulipe Terhadap Minat Konsumen Untuk Membeli ulang di Kota Banyuwangi,” vol. 20, 2015.

[22] P. Kotler, Manajemen Pemasaran Edisi 12 Jilid 12. Jakarta: Indeks, 2008.

[23] J. Riyadi, Gerbang Pemasaran. Jakarta: Gramedia, 1999.

[24] M. Alshurideh, R. M. d. T. Masa'deh, and B. Alkurdi, "The effect of customer satisfaction upon customer retention in the Jordanian mobile market: An empirical investigation," Eur. J. Econ. Financ. Adm. Sci., no. 47, pp. 69-78, 2012.

[25] N. N. Qonitat, I. Suyadi, and Sunarti, "Pengaruh Kepuasan Pelanggan, Switching Barrier dan Kepercayaan Merek Terhadap Customer Retention (Survei pada Mahasiswa S1 Universits Brawijaya Malang Pelanggan Produk Merek Wardah )," J. Adm. Bisnis, vol. 55, no. 2, pp. 5767, 2018.

[26] B. Odunlami, "Impact of Customer Satisfaction on Customer Retention: A Case Study of a Reputable Bank in Oyo, Oyo State. Nigeria," Int. J. Manag. Stud. Res., vol. 3, no. 2, pp. 42-53, 2015, [Online]. Available: www.arcjournals.org.

[27] N. Novianti, "Pengaruh Customer Satisfacton Dan Switching Barrier Terhadap Customer Retention," pp. 1-9, 2015. 